\title{
Correction: PDGFB-expressing mesenchymal stem cells improve human hematopoietic stem cell engraftment in immunodeficient mice
}

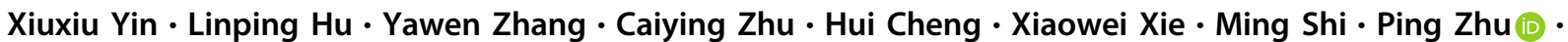 \\ Xueying Zhao - Wanqiu Chen · Lu Zhang - Cameron Arakaki - Sha Hao - Mei Wang • Wenbin Cao - Shihui Ma • \\ Xiao-Bing Zhang $\cdot$ Tao Cheng
}

Published online: 10 January 2020

(c) The Author(s) 2020. This article is published with open access

\section{Correction to: Bone Marrow Transplantation}

$$
\text { https://doi.org/10.1038/s41409-019-0766-z }
$$

Following the publication of this article incorrect labelling of the axis in Fig. 1c was noted. The $y$-axis title in this figure should read "\% CD34" instead of "\% CD45".

Open Access This article is licensed under a Creative Commons Attribution 4.0 International License, which permits use, sharing, adaptation, distribution and reproduction in any medium or format, as long as you give appropriate credit to the original author(s) and the source, provide a link to the Creative Commons license, and indicate if changes were made. The images or other third party material in this article are included in the article's Creative Commons license, unless indicated otherwise in a credit line to the material. If material is not included in the article's Creative Commons license and your intended use is not permitted by statutory regulation or exceeds the permitted use, you will need to obtain permission directly from the copyright holder. To view a copy of this license, visit http://creativecommons. org/licenses/by/4.0/. 
a
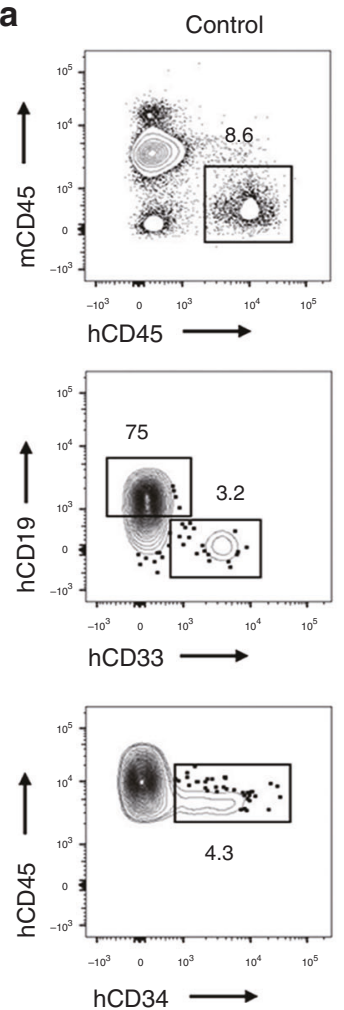

b

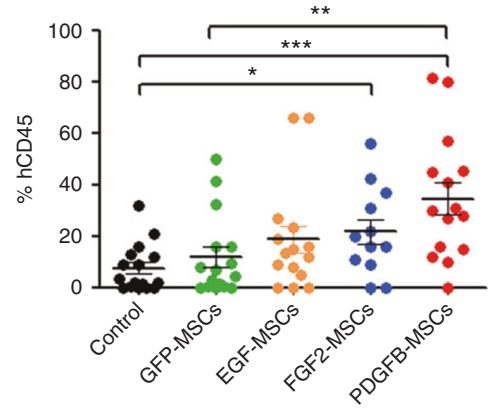

e

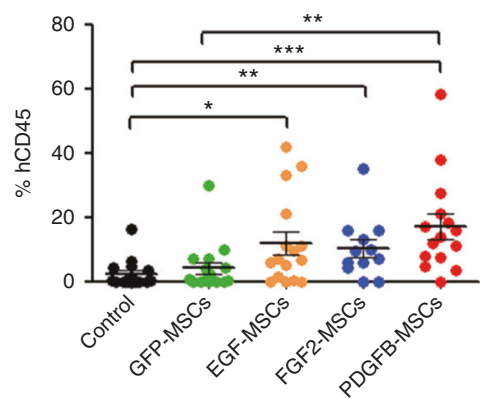

GFP-MSCs
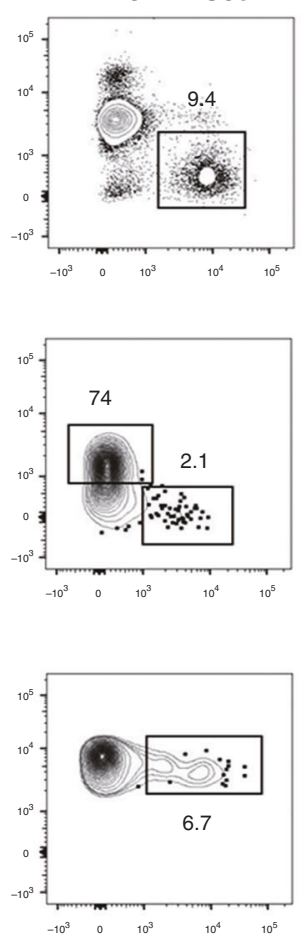

C

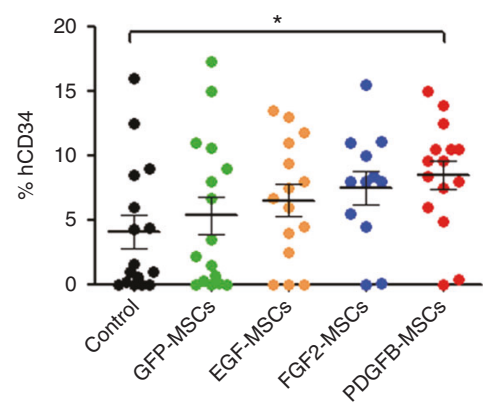

f
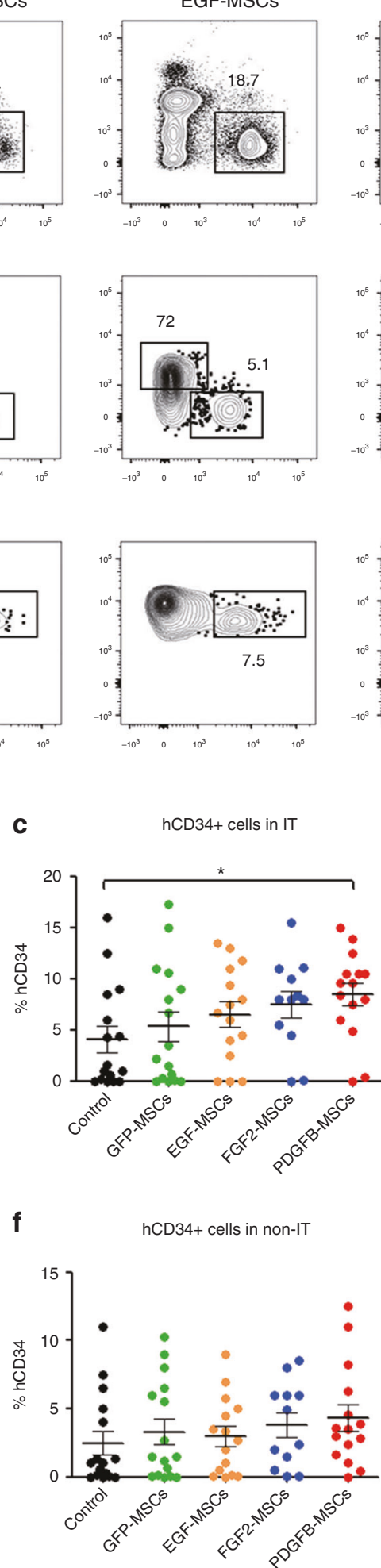

FGF2-MSCs
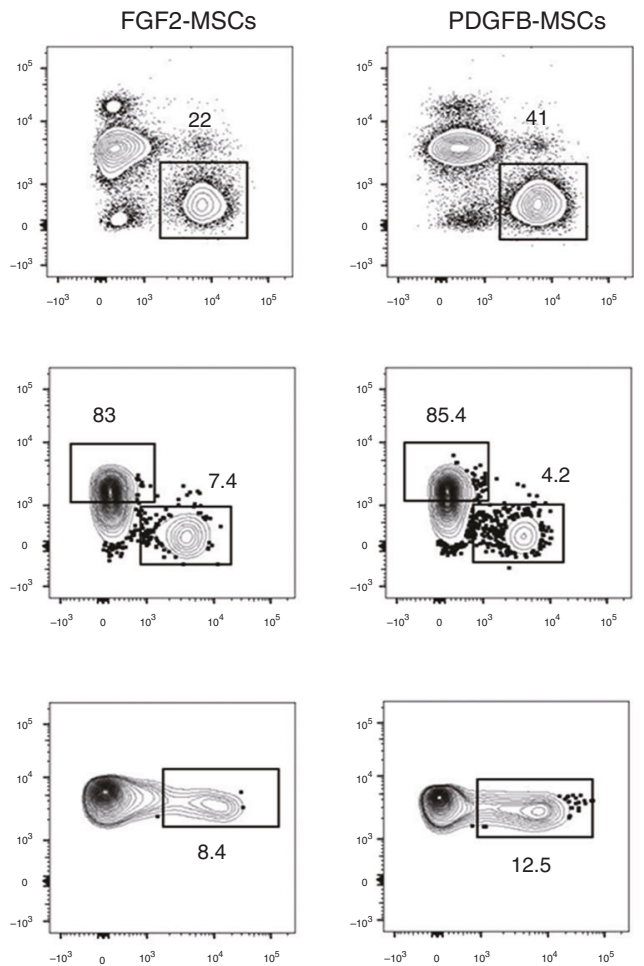

d

Lineage cells in IT

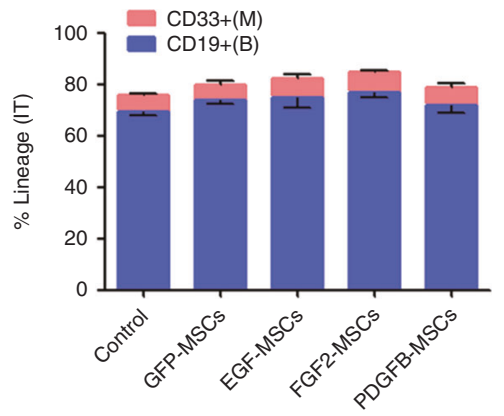

g

Lineage cells in non-IT

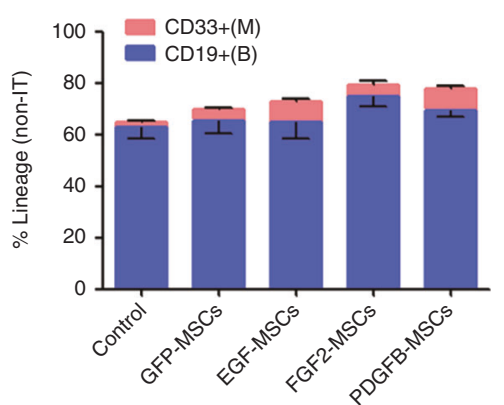

Fig. 1 